\title{
Still because of the weakness of some? A descriptive exploration of the Lord's Supper in South Africa, 1948-2002 ${ }^{1}$
}

C Wepener

(University of Stellenbosch)

\section{ABSTRACT}

\section{Still because of the weakness of some? A descriptive exploration of the Lord's Supper in South Africa, 1948-2002}

This article is a preliminary descriptive exploration of the celebration of the Lord's Supper in selected Reformed churches in South Africa over a period of 54 years. Methodologically, it employs a broad anthropological approach towards liturgy, thereby trying to reconstruct parts of the enacted ritual of the Lord's Supper from its historical debris. By making use of the comparative method, significant differences have been highlighted and interpreted. Throughout the article it becomes apparent how this Christian ritual was used to serve various political agendas, how cult and culture influence(d) one another. Finally, some tendencies have been extracted to be used in developing a criterion for the liturgical inculturation of the Lord's Supper as a ritual of reconciliation within the South African context.

\section{POINTS OF DEPARTURE}

"Die verlede is ' $n$ ander land: waar is die pad wat soontoe loop? Hoe moet mens begin? Teoreties is die moontlikhede onbeperk, en die verbeelding aarsel, oorweldig deur die oorvloed wat hom aangebied word. Beter is dit miskien om die vraag op meer konkrete en spesifieke wyse te herformuleer en te vra wáár mens moet begin" (Schoeman 1998:7). When discussing the celebration of the Lord's Supper in South Africa, where should one start? Must one start with the synod's decision in 1857 in respect of "the weakness of some" or go even further back to a possible Eucharist celebrated by Vasco da Gama and his company in the fifteenth century? Perhaps, rather, the more recent developments such as the Dutch Reformed Church's (DRC's) admission of children to the Lord's Supper in 1998?

1 Paper presented at an Expert Meeting of the Liturgisch Instituut, 19 April 2002 at the University of Tilburg and first published in 2002 in the Dutch Jaarboek voor liturgie-onderzoek 18, 139-158. I would like to thank Prof Hannes Adonis for his comments on and earlier version of this text. 
Perhaps an even better starting point would be the date that runs like "barbed wire" through our country's memory, namely, 19482. Yet, the "where", as point of departure, is not by itself adequate for looking back at the past, the "how" is also indispensable.

This article is an attempt to paint in broad brush strokes the celebration of this ritual. It is a very preliminary exploration of the celebration of the Lord's Supper in South Africa, aimed at a description of this ritual within a changing South African context. Specifically, the celebration of the Lord's Supper from 1948 until 2002 (inclusive) in respectively the DRC, the Dutch Reformed Mission Church (DRMC), the Dutch Reformed Church in Africa (DRCA) and the Uniting Reformed Church in South Africa (URC) ${ }^{3}$.

This article will focus only on one ritual, namely the Lord's Supper. The choice for this particular object of research is a conscious departure from only scrutinizing documents, confessions and declarations, towards looking at the actual ritual custom as practised in this period. An attempt is made to see how people in South Africa worshipped during this time, which could also indicate what they/we believe(d) (lex orandi lex credendi), to quote Prosper of Aquitania's motto in this manner .

Because of the choice of this particular object of research, the subsections, that are presented consecutively, are built thereon. Consequently, the frequency of the ritual will be viewed first, thereafter the participation and accessibility, the concomitant

2 The year 1948 was a turning point in our country's history, being the year that the National Party came into power, and apartheid then also was written into our country's law books.

3 The DRC is the oldest Reformed church in South Africa. The Afrikaans name of the DRC is the Nederduitse Gereformeerde Kerk (NGK), and not to be confused with the smaller Nederduitse Hervormde Kerk (NHK) and theen Gereformeerde Kerk in Suid-Afrika (GKSA). The so-called 'daughter churches' or 'mission churches' of the DRC were founded later, and as such along racial lines. Firstly the DRMC (Dutch Reformed Mission Church) was founded in 1881 for Coloured people, and later also the DRCA (Dutch Reformed Church in Africa) for Black people and the RCA (Reformed Church in Africa) for Indian people. In 1994 the DRMC and a large part of the DRCA merged to form the URC. (The decision for this merger took place during a meeting of their synods on the $17^{\text {th }}$ of April 1992, and Mr Nelson Mandela celebrated the Lord's Supper with them.) See Naudé (1995:140). 
formularies and prayers, physical involvement, the serving vessels and elements, symbols and symbolic acts and a few proposals concerning the Lord's Supper. These subsections are provided with an introductory perspective and close with a few concluding remarks.

The development of the above-mentioned ritual during the specific period will be viewed with a diachronic input. Where the development does not follow diachronically in some subsections, choices are based on the relevance of information for this inquiry. Since it is fairly difficult to describe certain developments within such a short period as 1948 to 2002; the current ritual practice with regard to reconciliation in the two different denominations will be discussed. This will be done with reference to liturgical sources and interviews. The latter descriptions will automatically give rise to a comparison $^{4}$ of what was and what is, as well as between the different ritual practices in the past and the present. Such a description can help to highlight areas where liturgical inculturation is needed.

As far as sources are concerned: primary and secondary sources were utilised. In this connection, primary sources refer to liturgy concerning reconciliation that members themselves experience(d), and secondary sources are publications on the ritual practice/liturgy, written by people who, themselves, are not necessarily involved in the practice (see Post 2001:59).

In conclusion, a number of lines of force, derived from the research, will be explained. As a whole this is a descriptive exploration of the celebration of the Lord's Supper in South Africa.

\section{BACKGROUND AND PREAMBLE}

The sacrament of Lord's Supper was one of the most important stimuli for the founding of separate Reformed Churches for Coloureds and Blacks, alongside the White DRC in South Africa. Although the decision had already been taken during a synodical

4 The comparative approach is an integral part of any research that aims to make a study of the culture of a congregation. So, for example, it is often recommended that one should attend a worship service that differs from the one being researched, in order to shed more light on the differences. See, Ammerman (1998:82-83,199) as well as Taft's (1999) plea for the comparative approach. 
meeting in 1857, the DRMC in South Africa was only officially founded in 1881. Here, it is interesting that the 'colour problem' and the question whether people of colour, accepted as members of the Churches through their confession and baptism - would receive the Lord's Supper together with where Christians was already raised at the synod in 1829. It is remarkable that objections to this did not come from the churches, but from the Kommisaris Politiek (Commissioner of Politics), and as follows: no discrimination or appearance of a person may be acknowledged at the serving and receiving of the Sacrament of Lord's Supper (see Kriel 1961:55). During the meeting of the synod in 1857, a separate service for White and Coloured people was again on the agenda, with many votes for and also against such a decision. Eventually, the proposal of Rev A Murray Snr was accepted with a large majority, viz The Synod deems it desirable and scriptural that our members from the Heathen, be admitted and inducted to our existing congregations, especially where this can be done; but where this regulation, because of the weakness of some, the promotion of the matter of Christ among the Heathen established, or yet to be established, will enjoy their Christian privileges in a separate building or establishment (Kriel 1961:58-59, see also Naudé 1995:133-134 and Theron 1986:194).

Thus, in the nineteenth century in South Africa, the Lord's Supper served as one of the main stimuli for the founding of a separate church on account of racial differences. This article also aims to examine the role of the Lord's Supper as it was implemented as an agent for and against apartheid; how the political system of a country is reflected in the Eucharist, as well as the potential that the Eucharist has with regard to reconciliation in post-apartheid South Africa. This is made possible because there is, throughout, always a significant interaction between cult and culture in any society. The culture of the relevant period necessarily influenced the liturgy, just as the liturgy attempted to influence the culture. As such, the

5 In this regard, Wallis (1989:3) comments forthrightly and unequivocally, "The Dutch Reformed Church is strictly divided into racial categories, the issue over which the powerful white leaders had finally divided the church was, ironically enough, communion. White worshipers refused to drink from the same cup as their black brothers and sisters". See also Boesak (1983) and Loff (1983). 
continuous interaction of cult and culture is also evident in this ritual ${ }^{6}$.

For various reasons, the formal celebration of the Eucharist in the DRMC, DRCA and the URC is celebrated similar to the description of the DRC's celebration ${ }^{7}$. Therefore, only where they differ from the DRC will a comparative examination be done, and the rest may be accepted to be similar to that of the DRC, and vice versa.

The influence of the Liturgical Movement of the $20^{\text {th }}$ century, and the liturgical developments within the worldwide Reformed family, reached the DRC during the fifties of the previous century and later. Thus, during the $23^{\text {rd }}$ Meeting of the Council of Churches of the DRC in 1953 it was asked that synods should seek uniformity in the liturgy by laying down the form of liturgy, thereby limiting the freedom of the liturgists. Consequently, a commission was assigned the task of seriously studying the liturgy for a number of years (Handelinge, Raad van die Kerke 1953:35). This commission's recommendations were received in 1959 in the Report of the Commission for Liturgical Review; this was an attempt to lay down a fixed service order for the DRC in a biblically justified way.

It is important to note that this commission made it clear from the start that they regarded the Scriptures as their point of departure and source, and that the central emphasis of the entire worship service should be the proclamation of the Word. Most of their proposals, and the particular way in which the Lord's Supper attained and kept its form in the ensuing years, must be understood from this point of departure (cf. Handelinge, Raad van die Kerke 1959:63-106). With regard to this greater liturgical consciousness in the DRC, Burger (2001:5) says, "In many ways it is ironic that this greater awareness of the liturgy happened during the same period when the DRC hardened its position on apartheid and the schism between the White and the Black and Coloured divisions of the DRC

6 Actually, the cult is such an inherent part of culture that the two concepts can hardly be separated. See Barnard (2001:47-62).

7 For the reasons, see Burger (2001:6). Among others that the DRMC and the DRCA had close ties with the DRC as the DRC supplied them with ministers who received their training at DRC institutions. 
was growing. In retrospect, this does not serve the cause of the liturgy well”.

When one reflects upon the pattern of the Eucharist, it is evident that a partial turning point only took place at the General Synod of the DRC in 1998. Besides the Scriptures, the history of the liturgy, as well as the anthropological phenomenon of rituality, were applied as criteria with regard to liturgical reflection. However, the end product of this new approach still awaits us in the future. The reality of the liturgy in local congregations is characterised by great diversity, ${ }^{8}$ which naturally also reflects in the Eucharist.

With the preceding points of departure and perspective in mind, a number of aspects of the celebration of the Lord's Supper in the past and the present will now be described.

\section{FREQUENCY}

As a consequence of the frequency of the Lord's Supper in the Reformed tradition, i.e. only four or five times per year, the emphasis on self-examination and a dignified use of the sacrament, together with an attempt towards a sharp delimitation of the ritual versus that of Rome, the Reformed Eucharist is traditionally celebrated over a period of three consecutive Sundays. However, like the current tendency in the world-wide Reformed family, the DRC and URC are also moving towards a more frequent celebration.

In 1959, Prof H D A du Toit, remarked in his study entitled, The service of the Sacrament that the power of the tradition is so strong that the quarterly celebration [of the Lord's Supper] will not easily be changed (Handelinge, Raad van die Kerke 1959:81-82). It was only the General Synod of 1978 that recommended an inquiry into the possibility of more frequent Eucharist services, and that a monthly celebration be contemplated. In 1986 the General Synod decided that the Eucharist should be celebrated more than at least four times a year, and in 1998 that, over and above Eucharist celebrations on other Sundays, congregations specifically also celebrate the Eucharist on the three Christ-festive-days, i.e.

8 This diversity can be roughly positioned under two denominators, viz. a more evangelical "praise and worship" line with a legacy of the American revival movement, the mega-churches and hymns of the Charismatic Churches, in contrast with a line that works in the direction of an enrichment of the traditional liturgy. See Burger (2001:5-6). 
Christmas, Easter Sunday and Pentecost ${ }^{9}$. However, by 1999, Vos (1999:120), a theologian of the DRC, took it even further by pleading for a weekly Eucharist celebration ${ }^{10}$.

However, the study of Bauswein and Vischer, dated 1999, contends that the current practice in the DRC and URC is still only four times per year, which means that the DRC and the URC, of all Churches with a Reformed confession in South Africa, celebrate the Eucharist the least frequently. This state of affairs is not according to Calvin's ideal, and should also be reviewed with a view to the Eucharist's potential as a reconciliation ritual.

\section{PARTAKING AND ACCESSIBILITY}

A further question that arises, is who received or may receive the Lord's Supper in the respective churches? Beukes (1994:24-25) speaks of the so-called more closed invitation to the Eucharist, which means that members from other congregations and churches must first announce their presence before they may partake of the Eucharist in the congregation in question. Du Toit (1989:95\&104) ${ }^{11}$ also points out how the General Synod of the DRC "see-sawed" between "open" and "closed" Communion, which had an influence on the practice in the local congregations. Thus, the General Synod of 1966 determined that visitors had to first obtain permission, and therefore engaged in "closed" Communion. The Synod of 1970, however, was in favour of "open" Communion, 1974 in favour of "closed" Communion, 1986 again in favour of "open" Communion and in 1990 the issue regarding "open Communion" was referred to the commission in charge of dogma and actuality issues for comprehensive investigation, which had to be fundamental and practical. This investigation was done and the General Synod of the DRC of 1994 endorsed the recommendations. It reads, inter alia, In congregations of the Dutch Reformed Church, visitors from both other congregations as well as other recognised Protestant Churches may partake of the Eucharist on condition that they have access and

9 Handelinge van die Sinode van die NGK (1978:862-863), also (1986:500\&544), as well as the Agenda van die Algemene Sinode van die NGK (1998:252).

10 See also, Wepener (2002a\&b) and Burger (2002).

11 See also the Kerkorde van die NGK in the relevant period. 
the freedom to do so in their own congregations ${ }^{12}$. At present, the "see-saw" at synodical level is much closer to a more open approach with regard to receiving the Lord's Supper than previously.

Although the DRMC and the DRCA maintained similar decisions regarding a more "closed" Eucharist" ${ }^{13}$, the whole policy of apartheid and concomitant separate worshipping caused a number of ministers of the DRMC and DRCA to refuse to partake of a Eucharist celebration of the World Council of Reformed Churches in Ottawa in $1982^{14}$. Because of the fact that, in South Africa, they were not allowed to celebrate the Eucharist with the White members of the DRC, they thus also refused to do so in Canada with the White members of the DRC. As mentioned above, a clear turning point is currently evident at synodical level in the DRC in favour of a more open view of the Eucharist. No preceding announcement is demanded, only personal faith in Jesus Christ and membership of $a$ recognised Protestant church.

Already early on, clerical ranks from various areas voiced their wish for a more open approach to the Eucharist and for communal worship in general. Thus, in 1982, Müller (1982:77) enquired, How serious and literal is our intention for the openness of the Supper? Is our closed Supper not in contrast with the Host's open heart? Also, in his article on this subject, Du Toit (1989:107) comes to this conclusion, As it is the Supper of the Lord through which he feeds his one church of all languages and nations, inter-communion should be practised as obedience to the Scripture and Lord of the church. However, by being satisfied with these examples an objective picture has not been sketched with regard to the openness of the Reformed Eucharist in South Africa. The following citations from a booklet of 1986, describes the diversity of standpoints better,

12 Agenda van die Algemene Sinode van die NGK (1994:84-88), and Handelinge van die Algemene Sinode van die NGK (1994:434).

13 See, i.a. Bepalinge en Reglemente van die NGSK (1966:41), and, Kerkorde en aanvullende bepalinge vir gebruik in die NGSK in SA (1990:51).

14 This event is viewed from various angles in De Gruchy \& Villa-Vicencio (1983). A similar incident occurred during the General Synod of the DRCA of 1983. The synodical meeting was, customarily, closed with a worship service consisting of a sermon and a celebration of the Lord's Supper. After the sermon, a whole group of ministers and elders (belonging to the so-called Confessing Circle) stood up and walked out, without partaking of the Lord's Supper. 
i.e. Antichristian powers grab it (communal worship) as an opportunity to create the kingdom of the antichrist. Therefore, we must be mindful of this. Also: He who says that apartheid is a heresy, proclaims the greatest heresy, because the opposite of that is integration and that is tantamount to building Babylon (Boshoff 1986:5\&20). These ranks do not even regard a communal celebration of the Eucharist as an option, and I cannot repeat their interpretation of the synod's decision of 1857 in this article out of respect for my Coloured and Black brothers and sisters.

Besides the question about the admission of non-members to the celebration, the question regarding the Lord's Supper for children was also tabled in the respective churches in this period. Thus, Prof. Russel Botman (2001), at the Southern Cape Regional Conference (SCRC) ${ }^{15}$ in his submission, Together and reconciled? told of the grace that he himself said as an elder the previous Sunday (therefore 04-03-2001) at the URC where he is a member. This prayer included, inter alia, the following: ...Lord forgive us, because: who is here at the table? Where is the DRC? Where are the children? Other than in the DRC, the children do not yet have access to the Eucharist in the URC, although it has been placed on the agenda of their General Synod ${ }^{16}$.

15 In the DRC, the Eucharist, together with the ritual of baptised members' public confession of faith, have traditionally also served as a rite of passage. It was part of a Christian transitional ritual for adolescents in the Reformed Churches, and this changed their status from a baptised member to a communicant. With the introduction of the Eucharist for children, this aspect of the Lord's Supper, as transitional ritual in the DRC, thus became obsolete, and resulted in the current hiatus in respect of transitional rituals in the DRC for this phase of life. However, in the URC the Eucharist still plays a fundamental role in this respect. The two most important writers on rites de passage are certainly Arnold van Gennep and Victor Turner, but for a handy summary in this respect, see Lukken (1999:82-84), Power (1999:131-143) as well as Grimes (2000:87150). Furthermore, the admission of children to the Lord's Supper in the DRC can be regarded as a victory. Nevertheless, from a ritual-anthropological viewpoint, one could ask whether enough substitutes at the ritual of public confession of faith have been designed to obviate the role of the first reception of the Eucharist.

16 See Skema van Werksaamhede en Handelinge van die tweede Algemene Sinode van die VGK (1997: 252-256). 
Although children during the apartheid years were not allowed to partake of the Eucharist, in certain ecumenical Eucharist celebrations, they held a special position. During those years the South African Council of Churches had a special section called, "Home and family life". This section, inter alia, worked towards enabling the church to focus on the well being of the family. So, there were special opportunities in which children and women from the struggle obtained a more prominent position in the Eucharist ritual ${ }^{17}$.

In congregations where participation for non-members is possible, the ritual is not always accessible to all. This is concomitant with the use of language during the Eucharist celebration. As from 1948 until the present day, the DRC celebrates the Eucharist in Afrikaans. The formulary has already been translated into several other languages, but not purposefully for use in Afrikaans DR congregations. This is understandable, although too rigid a language policy could make the Eucharist inaccessible for visitors. In the DRCA and DRMC, the Eucharist has been celebrated on many occasions during the apartheid years in English, Xhosa, or another South African language. Currently, many ministers in the URC strive towards the use of all the important languages in their celebration. Thus, Rev MacMaster points out how many hymns have one verse in Afrikaans and one verse in Xhosa, and he is of the opinion that the Reformed Eucharist in South Africa, in general, should move away from an exclusive use of language. Language in the liturgy, thus also in the Eucharist, is one of the stumbling blocks on the road to church unity between the URC and the DRC ${ }^{18}$.

\section{FORMULARIES, PRAYERS AND SERMONS}

Because of the prominent place of the formulary within the Reformed Eucharist celebration, it is crucial that a study, such as this, also covers the Eucharist formulary. It is almost impossible to discuss the formulary in theological detail in this article, therefore only a few important aspects are singled out.

The formulary that was used in the DRC during approximately 1949 requires that participants truly examine themselves before

17 From an interview with Rev Buys, 18.04.2001.

18 From an interview with Rev Nyatyowa, 16.05.2001. 
partaking of the Lord's Supper. This examination includes the mind, heart and conscience. As regards the conscience, it then asks that self-examination be done to determine whether a person has a serious intention of living in true love and harmony with his neighbour ${ }^{19}$. The question arises involuntarily: Who exactly was viewed here as the "neighbour" of the members of the DRC in this period?

De Visscher (1996:113) notes that, In all religions in their dealings with holy fare, such as meat offerings, bread offerings and consecrated wine or other alcoholic liquor, people provide protective taboos. These taboos protect a person against the undignified use of the holy food and drink, but it also protects the group. The group that gathers in the presence of their Host, and in community with each other, there communicate with each other and with God on a most intimate level. For this reason, their being together must be protected against possible Judases, who, through their presence, will profane the holy event. Precisely who the so-called Judases would be, is often spelled out in the protecting taboos, or, they will be indicated, at least, indirectly. So, the Eucharistic formulary that, inter alia, was in use during the period 1948 to 1969 in the DRC, has an especially long list of who were not allowed to partake in the Eucharist in the DRC, inter alia, all who did not obey their parents and governments. Of special importance is that this formulation, in the 1970 revision of the formulary, was extended to all who wish to cause a schism and disruption in churches and state governments, all who commit perjury and are disobedient to their parents and the government ${ }^{20}$. In retrospect, one does not need much imagination to see to whom this alludes! Beyers Naudé's (1995:155) interpretation of the formulary is in direct opposition with these taboos in favour of an open and inclusive Eucharist, namely that no Christian of another nation, class, race or colour who confesses the same Lord as Redeemer and subscribes to the same confession, may be refused the table of the Lord. Fortunately, the synod in 1974 also approved an alternative

19 See, i.a.: Drie formuliere van enigheid en die liturgie (Cape Town 1936) 150; Formulierboek van die Gefedereerde Nederduitse Gereformeerde Kerke in Suid-Afrika (Cape Town 1950) 27. These formularies that were/are used, are based on the classical-Reformed formularies that the DRC inherited from the Reformed churches in The Netherlands.

20 Handelinge van die Algemene Sinode van die NGK (1970: 727). 
Eucharist formulary from which these protective taboos were totally deleted.

The official Eucharist formularies of the DRMC and the DRCA were inherited from the DRC and were thus similar, except for the translation thereof. After the Black ministers joined the DRCA congregations in the seventies, the formulary was, however, partly liturgically inculturated. So, for example, the formulary was handled with in the utmost gravity, and the preceding sermon was extremely emotional and directed to profound self-examination. All the while they regularly sang and clapped their hands rhythmically while the members, church council and minister did much moving around in the liturgical area during, before and after the reading of the formulary. Rev Nyatyowa calls the Black cultures of South Africa "moving cultures," resulting in a Eucharist service taking two and a half to three hours" ${ }^{21}$.

Another outstanding difference regarding the DRCA formulary, which is currently also the practice in many black URC congregations, is the following: Just before the actual introductory words, all go to their brothers and sisters, shake hands, hug each other and say: "Ndixolele ukuba Ndikonile Ndiya kuthanda mzalwane/dade" 22 . During these events there is continuous singing, rhythmical movements, then all move back to their pews.

During the years of apartheid, the sermons and prayers in a Eucharist service often portrayed the South African context of that time. So, for example, in the prayers of certain DRCA congregations, the partakers of the Eucharist asked to be strengthened also, through the Eucharist, for the struggle, or they specifically prayed at the table for their white brothers and sisters. Similarly, much of the Eucharist preaching in the DRC supported the apartheid policy so that Rev Nyatyowa remarked, "Often through what they [DRC ministers] said during the sacrament they confirmed and rubberstamped the apartheid of the ungodly government" ${ }^{23}$.

21 From an interview with Rev Nyatyowa, 16.05.2001.

22 This is the Xhosa for "Forgive me if I have hurt you with anything, I love you my brother/sister." From an interview with Rev Nyatyowa, 16.05.2001.

23 From an interview with Rev Nyatyowa, 16.05.2001. 
In the DRCA the preaching also functions in a way that leads the congregation to self-examination in an emotional fashion. Therefore, all who "felt" the message go to the front to say, "Here I am, Lord, I wish to partake of this holy Eucharist". While all who intend to partake of the Lord's Supper stand in the liturgical area, the liturgist gives ample time for silence in which the communicants can confess their sins before $\mathrm{God}^{24}$.

\section{PHYSICAL INVOLVEMENT}

The DRC's General Synod of 1998 decided that partaking of the Eucharist might sometimes take place by way of the moving Communion, which entails that the Eucharist is served while the members move past the table (Agenda 1998:252). Beside the walking communion of the DRC, the URC's most recent Eucharist formulary $^{25}$, also attempts to promote members' physical involvement at the Lord's Supper. The congregation's participation is brought about by verbal responsorial participation, sitting down and standing, as well as by means of the greeting of peace. Similar physical involvement in the Lord's Supper also takes place in a number of DRC congregations. These developments are in line with developments in the world-wide Reformed family (see Wepener 2002b:655-659).

However, in the DRC, movement and physicality was limited traditionally to the minimum in the entire liturgy. This was partly for the sake of good order in the church, partly as a result of her cognitive-cerebral liturgical legacy, and partly because of the view that the Eucharist is a very personal matter between the partaker of the Lord's Supper and the Lord Jesus. The missionary ministers in the DRMC and the DRCA prescribed the same type of liturgy.

In 1988, Müller still described this state of affairs in the DRC as our cold, formal and reserved celebration of the Eucharist. You go and sit in your pew, you do not look left or right, you receive and use the elements and, for you, it is a mere issue between yourself and God. Therefore, he then asks whether the liturgy should not compel one to take note of each other during the Eucharist. Thus, the danger that people walk in with bad feelings towards each other, partake of

24 From an interview with Rev Nyatyowa, 16.05.2001.

25 See, Liturgiese diensordes, formuliere en litanieë (Belhar 1999), 9-14. 
the Eucharist, then walk out without attending to the problem, could be largely prevented (see Muller 1988:86).

However, physicality is much more noticeable in the Black and Coloured cultures than in the DRC, and a movement towards greater physical-sensory involvement during the liturgy in these churches thus accords. Rev MacMaster, for example, is of the opinion that the members of the URC are traditionally less intent on the rational and more on the experience. Also, many members in their daily walks of life often deal with charismatic Christians, and attending church services is a type of escape, getting away from daily life. The worship service is something that must be experienced actively, thus diverting the attention from the here and now and directing it onto a better future.

Physical involvement, with a special emphasis on music, rhythmic movements and dance, is part of the Eucharist of the DRCA and the Black URC congregations. It has also become evident from various descriptions in this article, and can be viewed as one of the most important liturgical differences between some DRC and URC congregations. This physical involvement also takes place during the Eucharist's offerings, which is viewed as an integral part of the ritual. Instead of the deacons going to the pews with plates or bags for the collection, some members have the need to take their offerings to God themselves. For them this is an expression of their gratitude to God, because "I want to feel happy and give my 'little bit' with my whole heart" 26 . Therefore, all sing a joyful song while they follow the minister and move to the front with music and dancing. Your offering (money) you hold in your hand, and when you move past the table, you slam your money into the plate on the table. This ritual is in contrast with the quiet collection of the offerings by the deacons from a sedentary congregation with organ music in the background, as happens in the DRC and many URC congregations.

\section{SERVING VESSELS AND ELEMENTS}

The custom in the DRC to serve the Eucharist wine in small glasses, as an alternative to the large chalice, became the general custom in 1918. The Lord's Supper was probably celebrated in this way for the

26 From an interview with Rev Nyatyowa, 16.05.2001. This is a description of the so-called "umjikelo" or "money slamming ritual". 
first time in the DRC on 8 January 1888 in the congregation of Riversdale (Barnard 1981:380 \& Van der Watt 1987:333) ${ }^{27}$. From a practical viewpoint this is a prudent arrangement when many people receive the sacrament simultaneously and this was the custom in most DRC, DRMC, DRCA and URC congregations. A similar custom regarding the bread is that the bread was cut into small square slices beforehand, and then served by the deacons.

According to the Report of the Commission for Liturgical Review of the DRC of 1959, the partaking of the bread and wine is a very personal matter between the communicant and the Lord Jesus, and must take place in the greatest silence and simplicity. As the Church became aware of the value of symbols, many congregations have already started to use one cup, and one whole loaf of bread that is broken. The nature of establishing community, symbolically, thus comes to the fore better, as all become visually aware of the fact that they share in óne body, just as there is only one loaf of bread and óne chalice. During the apartheid years the community-establishing character of the Eucharist was used by some DRMC liturgists to promote the feeling of solidarity with those who struggled together against the suppressive apartheid policy. So, for example, (tells a student who took part $)^{28}$ in the apartheid years in the student congregation of the University of the Western Cape, Dr Allan Boesak introduced the chalice and had students breaking the bread for each other. According to him, this promoted koinonia and the ritual strengthened the feeling that they were solidary with each other in the struggle against apartheid. This formation of the Eucharist within a specific context stands in glaring contrast to the individualistic view of the ritual of some in the DRC in 1959.

Both this individuality and communality, or so-called "solitary feeling," is closely linked to what Lukken (1999:68) calls the social dimension of rituals. A ritual (as e.g. the Reformed Eucharist) is directed at the individual, the "I" is in the foreground. But, Lukken explains that just as a ritual is an expression of myself, it is also directed at others. According to Lukken, a ritual evokes communality, it calls to others to communicate with me, and the

27 This way of celebrating the Lord's Supper is also known as communio sedentaria.

28 From an interview with Rev MacMaster, 05.04.2001. 
members, the group, and the community find their identity in and through the ritual. Because of the fact that communities realise themselves in and through their rituals, a person can learn to know a community well via its rituals. So, for example, we learn something here of various Christian communities in South Africa between 1948 and 2002 by means of the way in which they made use of the serving vessels and elements within the ritual of the Lord's Supper. On the one hand, it seems as though religion in the DRC was sometimes viewed as a personal matter between the individual and God. The Eucharist was thus directed more at a person's personal relationship with God, as symbolised in the perfectly symmetrical piece of bread and small glass of wine. In contrast, in certain DRMC and DRCA circles there was a more common and community-promoting comprehension of the ritual. Religion was viewed as a phenomenon that also penetrated social structures and the whole community, as symbolised by the whole loaf of bread that was broken for each other, and the one chalice from which all drank ${ }^{29}$.

An ecumenical Eucharistic liturgy of 1986 that could probably also have functioned in DRMC and DRCA congregations also strengthens this idea. When the liturgy proceeds to the sharing of the elements, it was the custom that the officiator hands the bread and chalice to the person closest to him/her, who, in turn, breaks off a piece of bread and takes a sip of wine, then hands the bread and chalice back to the officiator (see De Gruchy 1986:251).

In a booklet of 1992, to be used as a liturgical guideline together with the document, "The road to Damascus", the following proposal was made with regard to the Eucharist within the context of acute poverty in South Africa. Firstly, the (home-made or government's) bread, porridge (pap) or roti, the food of the poor in (the community) your environment, rather than the traditional waffles/hosti, should be used. Then the bread and wine must be shared in such a way that it confirms communality. Thus, people who do not normally distribute the bread and wine can do so with words such as "The bread of life broken for you", "Give us today

29 Here see Müller \& Smit (1991), according to which the liturgy and preaching of that time display a strong individualistic, subjective, vertical piety that should stimulate a person to dedication to God - a dedication, however, with precious little implications for the life in the church and the world (own translation). 
our daily bread", "The body of Christ, the bread of life", "Bread of the people, bread of life", "Bread of life shared among us" and "The blood of Christ shed for you", or alternative words. Within the cadre of the same service, the writers suggest that a candle, around which barbed wire has been turned, as a meaningful and powerful visual symbol for the freedom struggle in South Africa, can be utilised in the liturgy (Institute for the study of the Bible 1992:39-41) ${ }^{30}$.

Here, it is important to keep in mind that this last 1992 suggestion was made within the "already" and the "not yet" of the South African political situation. Nelson Mandela had already been liberated from jail, but he was not yet the State President. Furthermore, the ritual was specifically contextualized with the view to poverty. In his body, Christ was thus visually and symbolically partisan to the poor. Simultaneously, the fact that the believers already shared in Christ's victory was confirmed in the distribution and the words. So, the poverty-past of many South Africans was represented in the ritual, the freedom that Christ brings from current suppressive structures was celebrated, and a better richer future (perhaps also affirmative action?) anticipated. From the description of this ritual one sees that Lukken (1999:302) is right when he remarks that liturgy is a dangerous game, because in liturgy a reversal of values takes place. In this game it can be that the lost are found, the poor are satisfied and the rich go home with empty hands.

One way in which the Eucharistic ritual is already profoundly liturgically inculturated in the Xhosa culture and, as such, finds expression in the Lord's Supper of many URC congregations, is the way in which the elements are handled. In the Xhosa culture one eats traditionally only with one's hands. This cultural custom is reflected in the Lord's Supper by the pastor washing his or her hands in a basin of water before breaking the bread. According to Rev Nyatyowa, it is a cultural and hygienic custom because then all know this is clean food ${ }^{31}$.

30 The fact is encouraging that also the Synod of the DRC in 1998 asked for an investigation into the strong tie that exists (according to the New Testament and the History of Liturgy) between the Eucharist and the service of charity (own translation), (Agenda van die Algemene Sinode van die NGK 1998:256).

31 From an interview with Rev Nyatyowa, 16.05.2001. 


\section{FURTHER SYMBOLS AND SYMBOLIC ACTS}

To grasp the meaning of a symbol, define it correctly, or to try to reduce it to one meaning is a difficult or almost impossible task, because a symbol is essentially a polysemantic phenomenon. Therefore, a number of symbols that are closely linked to the Eucharistic ritual of the relevant period will now be described with only a few concomitant comments. The first example then is also a good example of the polysemantic nature of a symbol.

The URC has the custom to put an empty chair where the elders sit at the table during the celebration of Lord's Supper. The general interpretation of DRC members is that this empty seat symbolises the empty seat of the DRC in the unification process. It is a symbol of the dividedness and disruption of the two churches, but also symbolic with regard to the laborious process of church unification.

Of the validity of the symbol's latter explanation of the empty chair at the Eucharistic table in the URC, various ministers of the URC, inter alia, the moderator of the present General Synod of the URC, Rev James Buys, has no knowledge. He knows the custom of the empty chair only as a symbol in the context of apartheid, i.e. that the chair will remain empty as long as apartheid has not yet been abolished, or as long as (a) certain person(s) are still in custody. These explanations, however, do not dismiss the possible validity of the first explanation that confirms the polysemantic nature of the symbol.

As regards the absence of the DRC in the unification process, the custom, in fact, exists that only two of the three visible candles within the liturgical space of certain URC congregations are lit. The two burning candles then refer to the DRMC and the DRCA that have become united, and the unlit candle refers to the empty place of the DRC. The name of the Church, i.e. "Uniting," not "United," is also symbolic ${ }^{32}$. Furthermore, there is also a candle around which barbed wire is twisted that often burnt during celebrations of the Eucharist in the DRMC and the DRCA during the apartheid years. In this regard there is also the well-known example of a worship service broadcast of the SABC that was prohibited because such a

32 From interviews with Rev MacMaster, 05.04.2001, and Rev Buys, 18.04.2001. 
candle with barbed wire was in the liturgical area. Naturally, the candle symbolises Christ, who came as light to the world, and the barbed wire symbolises the context of apartheid, being the darkness that could not extinguish the light.

Both these candle-symbols also point, within their specific contexts, to the intrinsic tension that is characteristic of symbols. This intrinsic tension comprises a critique on the suppressing and alienating life on the one hand, and a promise, a real utopic anticipation of the reconciliation of true life on the other hand (see Lukken 1999:301-302) ${ }^{33}$. This intrinsic tension also clearly came to the fore in a celebration of the Lord's Supper in the Southern Cape during the apartheid years in which purposeful resistance against the forced removals of Coloureds and Blacks was built into the ritual. The tension was sometimes even taken further by events being purposely held on dates such as 21 March or $16 \mathrm{June}^{34}$. With the aid of these dates, the ritual was purposely linked to dates in the South African political reality of those years.

In the DRCA and in various URC congregations, there is/was the custom that the pastor himself served the entire church council with the bread and the wine. After all ate and drank, the pastor then fetches all the glasses from the church council. This beautiful symbolic act symbolises the service that the pastor is willing to render to his congregation, in following Christ's example.

\section{A FEW PROPOSALS}

Deist (1997) points out that, in the seventies, several white church councils decided that only Whites may enter their church buildings and that people of colour should rather be accommodated in private people's garages. Also, a minister of the previous DRMC was not allowed to enter a DRC pulpit, but had to stand below the pulpit as an eerwaarde (a title inferior to Reverend). With reference to this liturgical apartheid, together with other events from the apartheid past of the DRC, Deist then makes the following suggestion regarding an Eucharist service in the post-apartheid DRC. The congregation can ask themselves: what was the situation regarding

33 In this regard, Lukken warns that this type of liturgy must not be reduced to the "functional" type, and thus submits the liturgy to ethical-social activities.

34 Today these dates are respectively Human Rights Day and Youth Day. 
"the truth" in our congregation in the apartheid years. The answer to this will not be very hard to find. A congregational meeting where wronged persons in and outside of the immediate environment of the congregation tell their stories .... Ultimately, after confession, reconciliation could be done in a visible and symbolic way for the church's transgressions, and visible and audible forgiveness could be asked and granted. A meeting such as this could be closed with the Lord's Supper, during which people could recall Christ's conciliatory work and dedicate themselves anew to the truth and the Truth (Deist 1997:19, 20 \& 27)

This, therefore, is a proposal of an academic in 1997, with reference to the ministration of the Eucharist in the DRC. It is an attempt to present the past concretely and thereby avoiding any vagueness, thus bringing Christian reconciliation physically to the people. According to Deist, the church should be a space of grace, so that people will have the confidence to confess their transgressions to each other. Such a space of grace is also most important for the ministration of a reconciliation ritual, such as the Eucharist. Parallel to this, Rev Buys ${ }^{35}$ is convinced that the Eucharist can make a contribution with regard to reconciliation, as the discourse on reconciliation in South Africa by the year 2001 lies so close to amnesia that certain people are of the opinion that discourse on reconciliation belongs to the past. Deist's proposal on this point could, indeed, be of value, i.e. to counteract loss of memory and to describe the past in no uncertain terms. In this way the vagueness, with reference to the reason for reconciliation among people of different races could be eliminated, which would be an unavoidable first step in any conciliatory ritual.

Under the subtitle, "Utilising liturgical elements to promote reconciliation", Kritzinger (1998:153) says that churches must mobilise the full potential of their rituals and sacraments, especially the Eucharist, for reconciliation. "The Lord's table in congregations could become a TRT: a Truth and Reconciliation Table", which means that members get the opportunity to tell their stories of suffering or guilt at the table/altar, so that their needs could be addressed in a fitting way. Furthermore, Jesus also brings victims to

35 From an interview with Rev Buys, 18.04.2001. 
the table and therefore an empty chair could be placed at the table to represent those who, as victims, cannot attend.

According to Rev Nyatyowa, the best proposal regarding the Eucharist is that the URC and the DRC sit together at the table as a family and primarily discuss together the entire matter with reference to a liturgy for Blacks, Coloureds and Whites. Something feasible must be formulated for the entire DRC family, so that the liturgy, and specifically the Eucharist, can serve the ideal of church unity between the URC and the DRC, and generally promote reconciliation ${ }^{36}$.

\section{CONCLUSION}

As historiography, this article is a very preliminary descriptive exploration from my own perspective as researcher, and the perspective of a number of victims/ministers. But, I believe this bit of history can help South Africa to remember, and the DRC in particular - to quote the Afrikaans writer, Antjie Krog - "to die into reconciliation". And, here I wish to add, to also help those who are busy with the study of Liturgy, especially with the liturgia condenda, to bring Christ's "dying into reconciliation" also in the collective story. Therefore, we shall now first look at a few patterns that are present, secondly to what the ritual says about ourselves, and lastly, some questions and suggestions for further reflection.

The finding of patterns (see Vos 1999:101) is an important task of the liturgist. In this short historical overview of the ritual formation of the Lord's Supper in South Africa a number of patterns can, indeed, be detected. So, for example, in the Eucharistic rituals of all the churches discussed, a development from uniformity to pluriformity is evident. During the DRC's Meeting of the Council of Churches in 1953, there was a plea for uniformity regarding the liturgy and that the forms could be laid down (see, Handelinge van die Raad van Kerke van die NGK 1953:35). This plea was made with reference to the large-scale liturgical pluriformity during that time. However, should you enter a DR congregation's Eucharistic service today, you can never be sure what awaits you. Therefore, once again, there is liturgical pluriformity after attempts over many years to bring about uniformity. This development will probably go ahead so that again, in the near future, a plea will be made for

36 From an interview with Rev Nyatyowa, 16.05.2001. 
uniformity regarding the liturgy in the DRC. Nevertheless, this present period during which congregations and synods are open for experimentation and variety in the liturgy is a ritually fruitful time to be able to experiment with explicit reconciliation-directed Eucharist celebrations.

In rituals/liturgy, purely utilitarian liturgical actions often tend to acquire symbolic meaning. An example here is the symbolic function that the communio sedentaria has acquired within the DRC and URC. More importantly however is the symbolic function that language has acquired. Although the most practical solution concerning language will be to always celebrate the Eucharist in English in order to accommodate as many people as possible, such an action will undoubtedly cause major unhappiness in both the DRC and URC. Languages like Afrikaans and Xhosa have acquired different symbolic meaning. For many people in South Africa Afrikaans is the language of the oppressor, but for many Afrikaners the language is very dear to them, it is their mother tongue, it is the language in which they worship. What this pattern helps us with here, is to be aware of the fact that parts of liturgy can in fact acquire symbolic meaning, like the use of a specific language, and must as such be handled with the appropriate respect.

In general, this ritual also moved from a very individualistic character, to a much more communal ritual. Where the Eucharist was earlier especially directed vertically at the relation God-man, the horizontal dimension gradually also attained a more prominent place beside the vertical, to bring about the relation God-man-man. This development is evident in the wording of the formularies and litanies, in the physical-sensory involvement that grew, the serving vessels and elements, developments regarding participation and accessibility, the admission of children, as well as in many of the symbols and proposals for the road ahead.

In line with this escalation in communality, the political, economic and social reality of South Africa also attained stronger emphasis in the ritual of the DRC. Currently, daily life is taken up more purposefully in the liturgy of the $\mathrm{DRC}$, which forms a glaring contrast with the otherworldly Eucharistic liturgies of the DRC of the apartheid years.

A last trend that is especially evident in the last decade in the diverse formation of the ritual is the movement that could roughly be 
called a movement from protest to reconciliation. On the one hand, there is a shift (DRC) away from an exclusive ritual with protecting taboos directed to the politically otherwise-minded. Similarly, there is also a shift (DRMC and DRCA) away from an exorcising, politically involved and protesting ritual that anticipated the casting away of the suppressing yoke, on the other hand. The Eucharistic rituals of both the DRC and the URC moved to a more inclusive, reconciliation-directed ritual. Restoration and the healing of broken relations replaced the previous activist and suspicion-mongering activities.

Furthermore, it is important to see how the form of worship reveals much about the content of the faith. How we prayed in the past, the form that our liturgy/Eucharistic celebration took, revealed something of what we believed ${ }^{37}$. Therefore, this little snippet of history is like a mirror for the DRC. For the road to reconciliation such a mirror is indispensable, because the past may not be forgotten. Therefore, even the writing of this article could be seen as a (component of a) reconciliation ritual. But this and similar mirrors (such as the TRC) make people very angry. The facts from history are often denied and made suspicious by the previously explicitly privileged. According to the psychiatrist, Dr Kaliski, such a reaction, in fact, is a first step in dealing with the truth. "Previously people said nothing, now at least they are denying the information." This he compares with the first step of terminally ill patients, viz. denial, which is a vital step to reach the following steps (see Krog 1998a:195-196) ${ }^{38}$.

But, what are the grounds upon which we can defend a "separate" celebration today? Does our unreconciled and divided church not make a mockery of the very being of the sacrament of the Eucharist? To quote Geoffrey Wainwright's (1997:166) words, "the reality of the Gospel itself is called into question by disunity among Christians, and a fortiori the reality of the church which claims to have been brought into being by the Gospel. In an extreme case: can

37 Schreiter (1998:33-36) also points out how the patterns of worship and ways of congregational meetings divulge the implicit and explicit theologies of a congregation.

38 The five phases comprise: denial, anger and isolation, negotiation, depression and acceptance. 
the church proclaim and transmit a gift it shows no sign of possessing?" Nevertheless, it remains an open question whether we must first eliminate our doctrinal differences before we can partake of the Lord's Supper together, and whether the opposite is not really true, i.e. whether shared celebrations will not help us to eliminate the dividing differences. At the same time, it is also crucial to obtain a decisive answer as to whether the separate celebration of the Eucharist depends on actual fundamental doctrinal differences, and whether it does not still depend on the Synod's decision of $1857^{39}$.

Participatory observation and interviews made the difference between the DRC and URC's bodily sensory experience of the Lord's Supper (liturgy) apparent. The more cognitive-rational ritual with very little bodily movement that one encounters in the DRC, versus the moving and "moving" celebrations of the URC. The question here is how one can create a ritual that both traditions can appropriate. The same goes for the different experiences of time, namely the linear (punctual) shorter celebrations of the DRC, versus the more cyclical (flowing) longer celebrations of the URC. Here we are faced with a real challenge. De Gruchy takes it further and calls the liturgy of the Reformed tradition "aesthetically challenged" with a "liturgical deficit", "so that even the Lord's Supper becomes didactic instead of celebrative!" Therefore he sees the rediscovery of the aesthetic dimension and the appreciation of a sacramental life that is embodied as imperative to the renewal of the Reformed tradition. "We can learn a great deal here from certain developments within the Pentecostal movement where dance and other forms of art have been reintegrated into worship. This is also, I believe, a major point of contact with African Christianity" (see De Gruchy 2001:49).

This description, as a whole, and the above questions, in particular, can hopefully inspire us to reflect more on our rituals and

39 Wainwright, in principle, is opposed to intercommunion between churches that are divided. One exception, however, is "there do come points at which, short of the achievement of the envisaged full unity towards which they are praying and working, ecclesial communities that are converging in faith, order, and life may practice intercommunion. They will do so both in order to celebrate the measure of unity already reached and in order to gain strength for future progress" (Wainwright 1997:178). Would it be possible to apply this to the DRC and the URC? 
to search for good or better ways and words with which to break bread and share wine in our changing South African context.

\section{Consulted literature}

Agendas en Handelinge van die Algemene Sinode van NG Kerk, 1970, 1978, 1986, 1994, 1998.

Ammerman, $\mathrm{N}$ T et al (eds.) 1998. Studying congregations: A new handbook. Nashville: Abingdon.

Barnard, A C 1981. Die erediens. Pretoria: NGKB.

Barnard, M 2001. Dynamiek van cultus en cultuur, in: Barnard, M \& P. Post (eds). Ritueel bestek: Antropologisch kernwoorden van de liturgie. Zoetermeer: Meinema.

Bauswein J \& L, Vischer (eds) 1999. The Reformed family worldwide. A survey of Reformed Churches, theological schools, and international organisations. Grand Rapids: Eerdmans.

Beukes, M J du P 1994. Erediens II. Pretoria: Kital.

Bepalinge en Reglemente van die NGSK, 1966.

Boesak, A 1983. "Foreword" in: De Gruchy, J and C Villa-Vicencio (eds), Apartheid is a heresy. Cape Town: David Philip.

Boshoff H J 1986. Gesamentlike aanbidding - die ander kant van die saak. Pretoria: Sigma-Pers.

Botman R 2001. "Saam en versoen?" Submission at the Southern Cape Regional Conference, Bou saam aan hoop.

Burger C W 2001. "Reformed liturgy in the South African context". Unpublished text.

-, 2002. "Nagmaal in die NG Kerk - Tussen tradisie en vernuwing. Deel 3". NGTT 43(3\&4), 661-669.

De Gruchy, J W 1986. Cry Justice! Prayers, meditations and readings from South Africa. Londen: Collins Liturgical Publications.

De Gruchy J 2001. "The Future of the Reformed Churches in South Africa. Some Random Notes and Reflections". Scriptura 76, 43-49.

De Gruchy J \& C. Villa-Vicencio (eds) 1983. Apartheid is a heresy. Cape Town: David Philip.

Deist F 1997. Vergewe en vergeet? Oor waarheid en versoening in Christelike perspektief. Pretoria: J L van Schaik Godsdiensboeke.

De Visscher, J 1996. Een te voltooien leven. Kampen: Kok Agora.

Drie formuliere van enigheid en die liturgie 1936. Cape Town.

Du Toit, H 1989. “Ope, geslote en interkommunie”. NGTT XXX/1, 95 - 109.

Formulierboek van die Gefedereerde Nederduitse Gereformeerde Kerke in Suid-Afrika 1950. Cape Town.

Grimes, R L 2000. Deeply Into The Bone. Re-Inventing Rites of Passage. 
Berkeley/ Los Angeles/ Londen: University of California Press.

Handelinge, Raad van die Kerk, 1959.

Kerkorde en aanvullende bepalinge vir gebruik in die NGSK in SA, 1990.

Institute for the study of the Bible 1992. Repentance and conversion: Working in the church and community on "The road to Damascus". Pietermaritzburg: Cluster Publications.

Kriel, J C 1961. Die geskiedenis van die Nederduitse Gereformeerde Sendingkerk in Suid-Afrika 1881 - 1956. Dissertation D.Litt. et Phil. Pretoria: UNISA.

Kritzinger, J 1998. "Suggestions for the way forward". in: Du Toit, C W (ed). Confession and reconciliation: A challenge to the churches in South Africa. Proceedings of a conference held by the Research Institue for Theology and Religion at Unisa on 23 \& 24 March 1998. Pretoria: Unisa Press.

Krog, A 1998. Country of My Skull. London: Vintage.

Liturgiese diensordes, formuliere en litanieë, 1999. Belhar.

Loff, C 1983. "The history of a heresy." in: De Gruchy, J and C Villa-Vicencio, Apartheid is a heresy. Cape Town: David Phillip.

Lukken, G 1999. Rituelen in overvloed. Een kritische bezinning op de plaats en de gestalte van het christelijke ritueel in onze cultuur. Baarn: Gooi \& Sticht.

Müller, B A \& D J Smit 1991. "Godsdiens in die openbaar. Tendense in die openbare godsdiensprogramme van die SAUK”. NGTT XXXII/4, 652665.

Müller, B A 1982. "Lukas 14: 15 - 24”. in: Burger, C W, Müller, B A. en D J Smit (eds). Riglyne vir Nagmaalsprediking. Cape Town: NG KerkUitgewers.

Müller, J 1988. Die Erediens As Fees. Pretoria: NGKB.

Naudé, C F B 1995. My Land van Hoop. Die Lewe van Beyers Naudé. Cape Town/Pretoria/Johannesburg: Human \& Rousseau.

Post, P G J 2001. “"Introduction and application. Feast as a key concept in a liturgical studies research design"” in: Post, P G J et al (eds.). Christian Feast and Festival: The Dynamics of Western Liturgy and Culture. Leuven/ Paris/ Sterling, Virginia: Peeters.

Power, D N 1999. Sacrament. The Language of God's Giving. New York: The Crossroad Publishing Company.

Schoeman, K 1998. Verliesfontein. Cape Town: Human \& Rousseau.

Schreiter, R J 1998. "Theology in the Congregation: Discovering and Doing". in: Ammerman, $\mathrm{N} \mathrm{T}$ et al (eds). Studying Congregations. A New Handbook. Nashville: Abingdon.

Skema van Werksaamhede en Handelinge van die tweede Algemene Sinode 
van die VGK, 1997.

Taft, R F 1999. "Comparative Liturgy Fifty Years after Anton Baumstark (d. 1948): A Reply to Recent Critics". Worship 73(6), 521-540.

Theron, P F 1986. "Kerklike eenheid en natuurlike verskeidenheid". in: Kinghorn, J (ed), Die NGKerk en Apartheid. Johannesburg: Macmillan South Africa.

Van der Watt, P B 1987. Die Nederduitse Gereformeerde Kerk 1905 - 1975. Pretoria: NGKB.

Vos, C J A 1999. "Die Towertyd van Liturgie". Praktiese Teologie in SuidAfrika 14(1), 99-126.

Wainwright, G 1997. Worship with one accord: Where liturgy and ecumenism embrace. New York/ Oxford: Oxford University Press.

Wallis, J and J Hollyday (eds) 1989. Crucible of Fire. The Church Confronts Apartheid. Maryknoll: Orbis Books.

Wepener, C J 2002a. "Nagmaal in die NG Kerk - tussen tradisie en vernuwing. Deel 1". NGTT 43(3\&4), 641-651.

-, 2002b. "Nagmaal in die NGKerk - tussen tradisie en vernuwing. Deel 2". NGTT 43(3\&4), 652-660.

Semi-structured interviews:

Rev Buys, 18.04.2001.

Rev MacMaster, 05.04.2001.

Rev Nyatyowa, 16.05.2001. 